\title{
Thiosilane- and Organoselenosilane-Mediated Novel Access to 3,7-Disubstituted-1,2,5- trithiepanes and -1,2,5-dithiaselenepanes
}

\author{
Antonella Capperucci, Damiano Tanini, Cosimo Borgogni, \\ and Alessandro Degl'Innocenti* \\ Dipartimento di Chimica "Ugo Schiff," Università di Firenze, Via della Lastruccia 13, 50019 Sesto \\ Fiorentino, Italy
}

Received 31 January 2014; revised 21 March 2014

\begin{abstract}
The reaction of bis(trimethylsilyl) sulfide with different substituted thiiranes under tetrabutylammonium fluoride (TBAF) catalysis leads to the synthesis of 3,7-disubstituted-1,2,5-trithiepanes, through regioselective reaction of a thiosilane intermediate with another molecule of episulfide, followed by intramolecular oxidation of two sulfur units. When using bis(trimethylsilyl) selenide, the reaction with thiiranes and TBAF affords a smooth access to a novel class of disubstituted-1,2,5-dithiaselenepanes. (c) 2014 Wiley Periodicals, Inc. Heteroatom Chem. 25:678683,2014 ; View this article online at wileyonlinelibrary.com. DOI 10.1002/hc. 21157
\end{abstract}

\section{INTRODUCTION}

Sulfur-containing compounds are very interesting molecules for their applications in synthetic organic chemistry and for their properties as biologically active compounds. A large number of sulfurated systems have been shown to be odor-active and odorrelevant molecules in different kind of plants [1].

Correspondence to: Antonella Capperucci; e-mail: antonella .capperucci@unifi.it, antonella.capperucci@gmail.com.

Dedicated to 77th birthday of Professor Okazaki.

* Deceased, May 12, 2012.

Contract grant sponsor: MiUR, National Project PRIN 20102011 "Processi ossidativi e radicalici: aspetti innovativi ed applicazioni allo sviluppo di biopolimeri melanici e antiossidanti di rilevanza biomedica e tecnologica (PROxi)".

(c) 2014 Wiley Periodicals, Inc.
Several examples refer to aliphatic derivatives, and in recent years the interest toward thiaheterocyclic compounds has increased, owing to their utilization in different fields of organic chemistry, biochemistry, and food chemistry. Polysulfurated heterocycles represent as well an interesting class of compounds for their physical and chemical properties and synthetic utility [2]. Several cyclic polysulfides of different ring size have been isolated from marine bacteria, and a profile of the pharmaceutical and agrochemical properties was investigated [3].

In this context, seven-membered rings appear interesting structures, and synthetic processes to obtain cyclic trisulfides, such as trithiepane derivatives, have been reported. In general, these compounds have been obtained in moderate yields and in complex mixture of products $[2 c, 3 b, 4]$.

In addition, the past decades have witnessed a growing interest in the chemistry of organoselenium compounds, mainly due to their antioxidant, antitumoral, and antimicrobial activities [5]. Among these compounds, selenides, diselenides, and seleniumcontaining heterocycles have attracted considerable attention for their useful reactivity in organic synthesis and potential biological applications [6].

Our long-dated interest in the chemical behavior of bis(trimethylsilyl)sulfide (HMDST) [7] led us to elucidate its efficiency as a useful reagent in the ring opening of epoxides and more recently of thiiranes, leading to a direct and regioselective access to $\beta$-mercaptoalcohols and 1,2-dithiols [8]. These bifunctional compounds behave as very efficient 


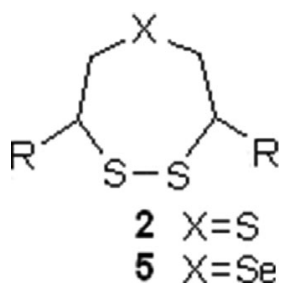

FIGURE 1 Structure of 3,7-disubstituted-1,2,5-trithiepanes and -1,2,5-dithiaselenepanes.

reagents for obtaining a variety of silylated five-membered heterocycles, such as 2-silyl-1, 3-oxathiolanes and -1,3-dithiolanes [8b,8c].

During the course of an investigation on the synthesis of different heterocyclic systems through the reactivity of thiosilanes and selenosilanes, we turned our attention to seven-membered thiaheterocycles of types 2 and 5, namely 1,2,5-trithiepanes and 1,2,5dithiaselenepane (Fig. 1).

To the best of our knowledge, only few examples are reported in the literature for the synthesis of the sulfurated derivative [2c,3b,4], whereas no example is present for the selenated analogue.

In this context, we thought that thiosilanes and selenosilanes could provide a convenient access to these molecules through the reaction with episulfides, followed by intramolecular oxidative ring closure.

\section{RESULTS AND DISCUSSION}

With this concept in mind, we reacted 2 equiv of 2-(5-hexenyl)thiirane 1a with HMDST under the catalysis of tetrabutylammonium fluoride (TBAF). The reaction proved quite efficient, leading to the formation of 3,7-di(5-hexenyl)-1,2,5-trithiepane $\mathbf{2 a}$ as ca. 1:1 mixture of cis/trans diastereoisomers (Scheme 1).

A reasonable mechanism for the formation of compound 2a is proposed in Scheme 2. On the basis of our previous results in the fluoride ion induced ring opening of episulfides with HMDST, the formation of the substituted $\beta$-dithiosilane intermediate 3 can be expected. This in turn should react with another equivalent of thiirane, leading, after the ox- idation of two sulfur units of intermediate $\mathbf{4}$, to the target trithiepane $\mathbf{2 a}$.

Taking into account that the ring opening of episulfides by thiosilanes proceeds in a regioselective way $[8 \mathrm{~b}, 8 \mathrm{c}]$ with the attack on the less substituted position, the formation of the isomeric 3,6disubstituted-1,2,5-trithiepane can be excluded.

The structure of $\mathbf{2 a}$ was assigned by NMR and mass spectra (MS) investigation, and by comparison with the literature data reported on analogue derivatives [3b,4b]. GC/MS analysis revealed the presence of two peaks with very close retention times (15.43 and $15.52 \mathrm{~min}$ ) and very similar MS. Mass spectrometric fragmentation contains a characteristic ion at $m / z, 206\left[\mathbf{M}^{+} \cdot-\mathrm{C}_{8} \mathrm{H}_{14}\right]$, which suggests the formation of a 4-substituted-1,2,3-trithiolane substructure. Other characteristic ions are at $\mathrm{m} / \mathrm{z} 141$ $\left[\mathrm{C}_{8} \mathrm{H}_{13} \mathrm{~S}\right]^{+}$and $109\left[\mathrm{C}_{8} \mathrm{H}_{13}\right]^{+}$. Proton NMR spectra appear to be second-order spectra, due to chemical nonequivalence of the methylene protons, while ${ }^{13} \mathrm{C}$ NMR shows signals in agreement with the proposed symmetric structure, while in the unsymmetrical 3,6-disubstituted trithiepane all carbon atoms are differentiated, due to the missing symmetry plane. As already described in the literature [3b], the complexity of proton spectra can be also due to rapid ring interconversion of the thiepane ring, thus showing broad signals.

To evaluate the generality of such methodology, a series of substituted episulfides was reacted under the same conditions. Results are summarized in Table 1.

The reactivity proved general, leading in good yields to the synthesis of trithiepanes $\mathbf{2 a - i}$, bearing different moieties, that could be further elaborated. The reaction is operationally simple and represents a direct, smooth access to cyclic polysulfides. Purification on silica gel allowed the isolation of products as a mixture of diastereoisomers, which were difficult to separate. Because of the mildness of experimental conditions, this procedure can also be applied to very useful, but more labile compounds, such as thioglycidol derivatives, which can represent versatile structures to be further functionalized. In fact, protected thioglycidols $\mathbf{1 e - i}$ reacted in good

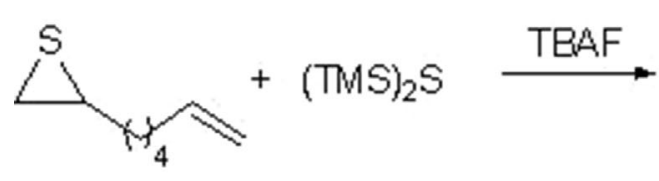

$1 a$

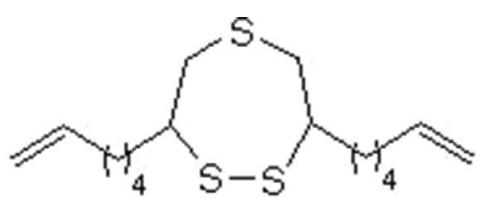

$2 a$

SCHEME 1 Reaction of thiirane with HMDST. 


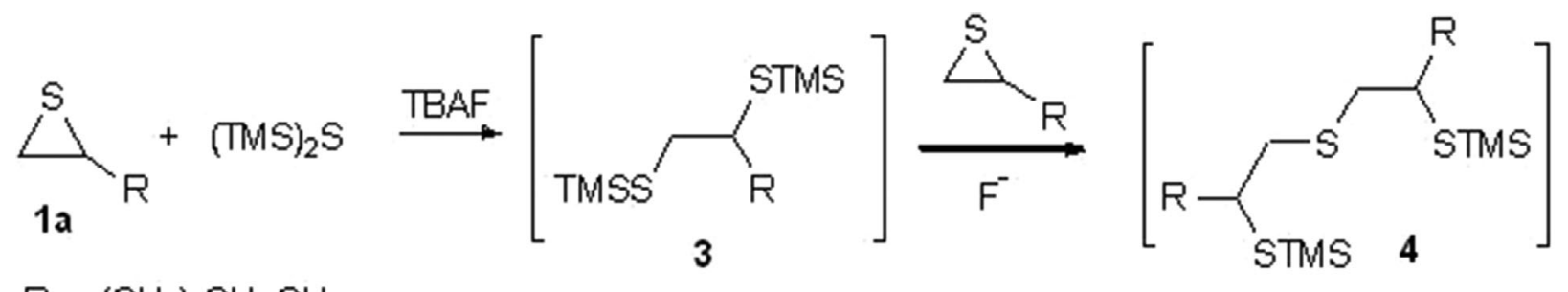

$$
\mathrm{R}=-\left(\mathrm{CH}_{2}\right)_{4} \mathrm{CH}=\mathrm{CH}_{2}
$$

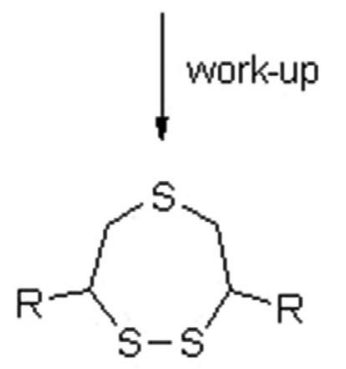

2a

SCHEME 2 Proposed mechanism.

TABLE 1 Synthesis of 3,7-Disubstituted-1,2,5-trithiepanes 2

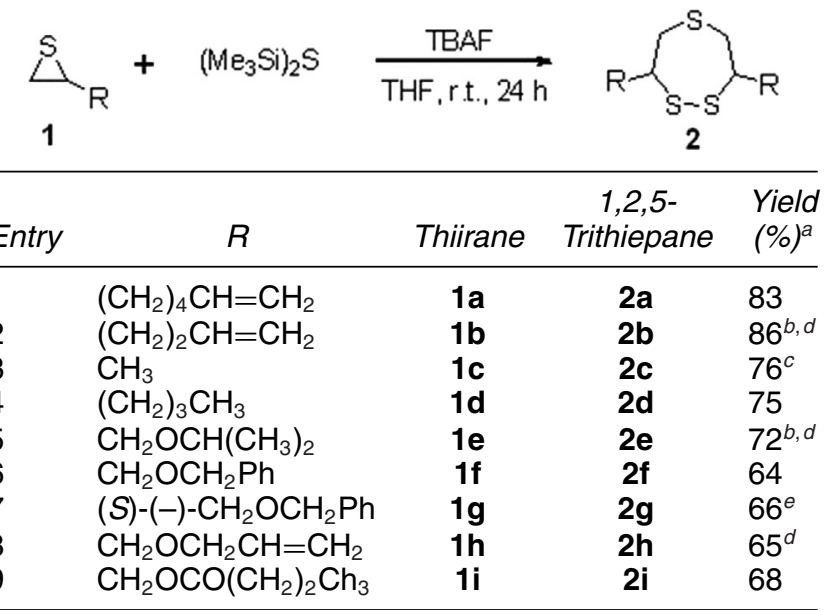

${ }^{a}$ After purification. Isolated as a mixture of diastereoisomers.

${ }^{b}$ Refers to the crude product.

${ }^{c}$ See references $[4 a-c]$.

${ }^{d}$ Isolated yield not optimized.

e Single diastereoisomer.

yields, and the protective groups were not removed under these conditions (Table 1, entries 5-9). When enantiopure thiirane $\mathbf{1} \mathbf{g}$ is reacted, trithiepane $\mathbf{2} \mathbf{g}$ is formed as a single diastereoisomer, due to enantioselective ring opening of the episulfide $[8 b, 8 c]$.

Taking into account the interest in the evaluation of the biological activity of small sulfurated cyclic structures, it is noteworthy to underline that the so obtained compounds, with different substituents and different polarity, could represent interesting substrates to be tested for applications in pharmaceutical or agrochemical field.
Once we established the efficiency of HMDST/ TBAF in the formation of trithiepanes, we turned our attention to the reactivity of the corresponding selenium derivative bis(trimethylsilyl)selenide (TMSSe-TMS, HMDSS). This compound has received less attention with respect to the analogue HMDST, despite the relevance that organoselenium compounds have actually gained.

We recently reported our preliminary results in HMDSS-induced regioselective ring opening of epoxides and episulfides, leading to the formation of $\beta$-functionalized diselenides or selenols [9].

Thus, on the basis of these results, we decided to evaluate the efficiency of HMDSS in the synthesis of unreported 1,2,5-dithiaselenepane derivatives. In a test reaction, thiirane $\mathbf{1 b}$ was reacted under TBAF catalysis at $0^{\circ} \mathrm{C}$ with HMDSS (Scheme 3).

The reaction proved quite efficient, affording as a predominant product 3,7-di(but-3-en-1-yl)-1,2,5dithiaselenepane 5a in good yield, together with minor amount (ca. 10\%) of the corresponding eight-membered 3,8-disubstituted-1,2,5,6dithiadiselenocane, arising from the oxidation of both sulfur and selenium units of the selenium intermediate (analogue of $\mathbf{3}$ described in Scheme 2). A mechanism similar to that proposed in Scheme 2 can in fact be responsible for the formation of $\mathbf{5 a}$.

This result was interesting, showing that under these mild conditions the silyl selenide intermediate (analogue of $\mathbf{4}$ in Scheme 2) was stable enough to attack another molecule of thiirane, minimizing the well-known high tendency of selenol derivatives to be oxidized. 


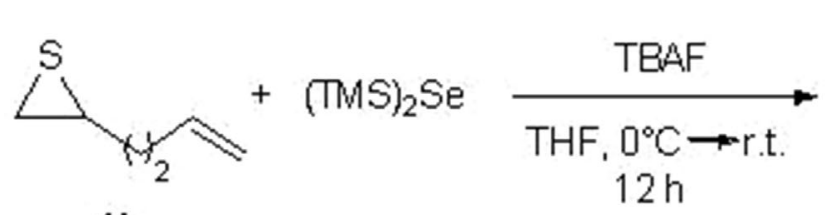

$1 \mathrm{~b}$

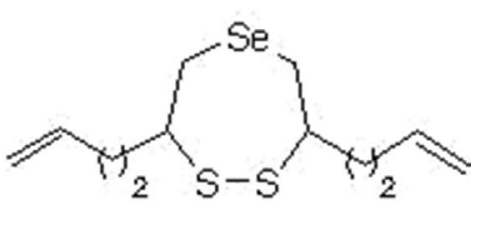

$5 a$

SCHEME 3 Reaction of thiirane with HMDSS.

TABLE 2 Synthesis of 3,7-Disubstituted-1,2,5-dithia selenepanes 5

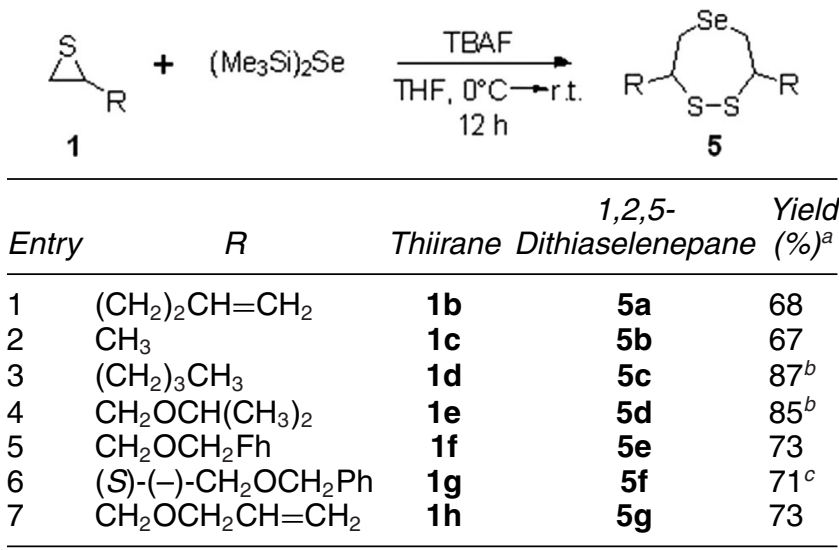

${ }^{a}$ After purification. Isolated as a mixture of diastereoisomers.

${ }^{b}$ Yield refers to the crude product.

${ }^{c}$ Single diastereoisomer.

Similarly to what was described for the sulfur analogue, the structure of dithiaselenepane 5a was also determined on the basis of MS and NMR data, which indicate the formation of a symmetric structure, arising from the expected regioselective ring opening of thiirane through attack on the less hindered position. Then, with the aim to evaluate the limits and the potential of this reaction, thiiranes with different substituents were reacted. The studied examples are listed in Table 2. They are showing the versatility of this synthetic approach to a novel class of mixed thia-seleno heterocycles.

\section{CONCLUSIONS}

We have devised a general and convenient access to differently 3,7-disubstituted-1,2,5-trithiepanes and -1,2,5-dithiaselenepanes through the reaction of thiiranes with HMDST and HMDSS, followed by intramolecular oxidative cyclization.

The reactions occur in a regioselective way and stereoselective formation of seven-membered heterocycles is observed when an enantiopure thiirane is used as a substrate.

Investigation on possible applications of the obtained compounds and optimization for purification procedures are currently being investigated in our laboratory.

\section{EXPERIMENTAL}

\section{General}

NMR spectra were recorded at 200, 300, and $400 \mathrm{MHz}\left({ }^{1} \mathrm{H}\right)$; 50 and $100 \mathrm{MHz}\left({ }^{13} \mathrm{C}\right)$; and $38 \mathrm{MHz}$ $\left({ }^{77} \mathrm{Se}\right.$ ) in $\mathrm{CDCl}_{3}$ (reference $7.26 \mathrm{ppm}$ for ${ }^{1} \mathrm{H}, 77.0 \mathrm{ppm}$ for ${ }^{13} \mathrm{C}, 461 \mathrm{ppm}$ for ${ }^{77} \mathrm{Se}$-external ref. $\left.(\mathrm{PhSe})_{2}\right)$. MS were obtained at $70 \mathrm{eV}$ ionization potential. THF was distilled prior to use from sodium/benzophenone. Flash column chromatography was performed using silica gel (230-400 mesh).

Synthesis of 1,2,5-Trithiepanes (2). General Procedure. A solution of thiirane $1(2 \mathrm{mmol})$ and HMDST $(1 \mathrm{mmol})$ in distilled THF $(3 \mathrm{~mL})$ was treated under inert atmosphere at room temperature with TBAF ( $0.2 \mathrm{~mL}$ of $1 \mathrm{M}$ THF solution, $0.2 \mathrm{mmol})$. After stirring at room temperature for about $24 \mathrm{~h}$, the solution was diluted with diethyl ether, washed with water then with brine, and dried over $\mathrm{Na}_{2} \mathrm{SO}_{4}$. The solvent was evaporated under vacuum affording a crude product, which was purified on silica gel (petroleum ether/diethyl ether).

3,7-Di(hex-5-en-1-yl)-1,2,5-trithiepane (2a). A mixture of two diastereoisomers $(83 \%) ;{ }^{1} \mathrm{H}$ NMR $\left(300 \mathrm{MHz}, \mathrm{CDCl}_{3}\right) \delta \mathrm{ppm}: 1.27-1.55(\mathrm{~m}, 12 \mathrm{H}), 2.01-$ $2.10(\mathrm{~m}, 4 \mathrm{H}), 2.75-2.98(\mathrm{~m}, 2 \mathrm{H}), 3.00-3.27(\mathrm{~m}, 4 \mathrm{H})$, 4.91-5.03 (m, 4H), 5.65-5.88 (m, 2H); ${ }^{13} \mathrm{C}$ NMR $\left(50 \mathrm{MHz}, \mathrm{CDCl}_{3}\right) \delta$ ppm: 26.7, 28.6, 33.5, 33.8, 41.2, 42.7, 114.5, 138.6; MS m/z (\%): $316\left(\mathrm{M}^{+}, 15\right), 206$ (18), 141 (30), 109 (31), 95 (11), 87 (27), 79 (23), 67 (99), 55 (54), 41 (100).

3,7-Di(but-3-en-1-yl)-1,2,5-trithiepane (2b). A mixture of two diastereoisomers $(86 \%) ;{ }^{1} \mathrm{H}$ NMR $\left(300 \mathrm{MHz}, \mathrm{CDCl}_{3}\right) \delta: 1.46-1.75(\mathrm{~m}, 4 \mathrm{H}), 2.01-2.38$ (m, 4H), 2.68-3.15 (m, 6H), 4.95-5.06 (m, 4H), 5.66$5.85(\mathrm{~m}, 2 \mathrm{H}) ;{ }^{13} \mathrm{C}$ NMR $(50 \mathrm{MHz}, \mathrm{CDCl} 3) \delta: 22.9$, 24.0, 30.9, 31.2, 32.7, 33.0, 41.2, 115.4, 137.4; MS $\mathrm{m} / \mathrm{z}(\%): 260\left(\mathrm{M}^{+}, \mathrm{9}\right), 227(3), 178(5), 159(6), 145$ (10), 113 (39), 105 (12), 99 (18), 85 (15), 73 (17), 67 (29), 53 (24), 81 (100). 
3,7-Dimethyl-1,2,5-trithiepane (2c). A mixture of two diastereoisomers (76\%); ${ }^{1} \mathrm{H}$ NMR $(200 \mathrm{MHz}$, $\left.\mathrm{CDCl}_{3}\right) \delta$ ppm: 1.24-1.42 (m, 6H), 2.86 (bdd, $J=$ $14.6 \mathrm{~Hz}, 7.4 \mathrm{~Hz}, 2 \mathrm{H}$ ), 3.09 (bdd, $J=14.6 \mathrm{~Hz}, 3.8 \mathrm{~Hz}$, $2 \mathrm{H}), 3.16-3.31(\mathrm{~m}, 2 \mathrm{H})$; MS $m / z(\%): 180\left(\mathrm{M}^{+}, 68\right)$, 147 (11), 138 (33), 115 (23), 64 (21), 74 (85), 64 (21), 59 (32), 41 (100).

3,7-Dibutyl-1,2,5-trithiepane (2d). A mixture of two diastereoisomers (75\%); ${ }^{1} \mathrm{H}$ NMR $(200 \mathrm{MHz}$, $\left.\mathrm{CDCl}_{3}\right) \delta$ ppm: 0.85-0.96 (m, 6H), 1.24-1.65 (m, $12 \mathrm{H}), 2.64-3.33(\mathrm{~m}, 6 \mathrm{H}) ;{ }^{13} \mathrm{C} \mathrm{NMR}\left(50 \mathrm{MHz}, \mathrm{CDCl}_{3}\right)$ $\delta$ ppm: 13.6, 13.9, 19.7, 22.4, 23.9, 29.4, 33.3, 33.7, 42.2, 51.1, 58.7; MS m/z (\%): $264\left(\mathrm{M}^{+}, 16\right), 231(3)$, 199 (10), 180 (21), 115 (31), 87 (17), 83 (38), 55 (90), $41(100)$.

3,7-Bis (isopropoxymethyl)-1,2,5-trithiepane (2e). A mixture of two diastereoisomers (72\%); ${ }^{1} \mathrm{H}$ NMR $\left(300 \mathrm{MHz}, \mathrm{CDCl}_{3}\right) \delta$ ppm: 1.11-1.15 (m, 12H), 2.93$3.41(\mathrm{~m}, 6 \mathrm{H}), 3.48-3.77(\mathrm{~m}, 6 \mathrm{H}) ;{ }^{13} \mathrm{C}$ NMR $(50 \mathrm{MHz}$, $\left.\mathrm{CDCl}_{3}\right) \delta$ ppm: $21.8,21.9,22.0,34.1,34.5,50.5,52.8$, 69.2, 69.8, 72.2; MS $\mathrm{m} / \mathrm{z}(\%): 296\left(\mathrm{M}^{+}, 3\right), 236(2)$, 196 (1), 136 (3), 99 (56), 73 (28), 57 (100).

3,7-Bis((benzyloxy)methyl)-1,2,5-trithiepane (2f). The product was purified by flash column chromatography (petroleum ether/diethyl ether 15:1) to give $\mathbf{2 f}$ as a mixture of two diastereoisomers. Yellow oil $(64 \%) .{ }^{1} \mathrm{H}$ NMR $\left(400 \mathrm{MHz}, \mathrm{CDCl}_{3}\right) \delta \mathrm{ppm}$ : 2.93-3.42 (m, 6H), 3.58-3.79 (m, 4H), 4.50-4.55 (m, 4H), 7.28-7.36 (m, 10H); ${ }^{13} \mathrm{C} \mathrm{NMR}\left(50 \mathrm{MHz}, \mathrm{CDCl}_{3}\right) \delta$ ppm: 39.9, 50.6, 70.1 , 73.2, 127.7, 128.6, 129.7, 137.9; MS $m / z(\%): 392\left(\mathbf{M}^{+}, 2\right), 301$ (1), 284 (1), 195 (2), 147 (9), 105 (5), 91 (100). Elemental analysis: calculated for $\mathrm{C}_{20} \mathrm{H}_{24} \mathrm{~S}_{2} \mathrm{O}_{3}$ : C, 61.19; $\mathrm{H}, 6.16$. Found: $\mathrm{C}$, 61.34; H, 6.34.

(3S, 7S)-3,7-Bis((benzyloxy)methyl)-1,2,5-

trithiepane $(\mathbf{2 g})$. The product was purified by flash column chromatography (petroleum ether/diethyl ether 15:1) to give $\mathbf{2 g}$. Yellow oil (66\%). ${ }^{1} \mathrm{H}$ NMR $\left(200 \mathrm{MHz}, \mathrm{CDCl}_{3}\right) \delta$ ppm: 2.98-3.39 (m, 6H), 3.60-3.78 (m, $4 \mathrm{H}), 4.53-4.55(\mathrm{~m}, 4 \mathrm{H}), 7.32-7.36(\mathrm{~m}$, $10 \mathrm{H}) ;{ }^{13} \mathrm{C}$ NMR $\left(50 \mathrm{MHz}, \mathrm{CDCl}_{3}\right) \delta \mathrm{ppm}: 34.2,50.2$, $70.1,73.2,127.7,128.1,128.4,137.8$; MS $m / z$ (\%): $392\left(\mathrm{M}^{+} \cdot, 2\right), 301$ (1), 284 (1), 195 (2), 147 (9), 105 (5), 91 (100).

3,7-Bis((allyloxy)methyl)-1,2,5-trithiepane (2h). The product was purified by flash column chromatography (petroleum ether/diethyl ether 3:1) to give $\mathbf{2 h}$ as a mixture of two diastereoisomers. Yellow oil $(65 \%) .{ }^{1} \mathrm{H}$ NMR $\left(300 \mathrm{MHz}, \mathrm{CDCl}_{3}\right) \delta \mathrm{ppm}$ : 2.96-3.25 (m, 6H), 3.50-3.75 (m, 4H), 3.97-4.03 (m, 4H), 5.17-5.31 (m, 4H), 5.78-5.98 (m, 2H); ${ }^{13} \mathrm{C}$ NMR (50 MHz, $\left.\mathrm{CDCl}_{3}\right) \delta$ ppm: 34.2, 34.3, 46.8, 47.1, 71.7, 72.1, 117.1, 134.6; MS m/z (\%): $292\left(\mathrm{M}^{+}\right.$, 2), 235 (32), 177 (8), 105 (18), 97 (100), 73 (64), 55 (71).
(1,2,5-Trithiepane-3,7-diyl)bis(methylene) Dibutyrate (2i). A mixture of two diastereoisomers (68\%); ${ }^{1} \mathrm{H}$ NMR $\left(300 \mathrm{MHz}, \mathrm{CDCl}_{3}\right) \delta$ ppm: 0.92-0.97 (m, $6 \mathrm{H}), 1.57-1.74(\mathrm{~m}, 4 \mathrm{H}), 2.26-2.35(\mathrm{~m}, 4 \mathrm{H}), 2.79-3.41$ (m, 6H), 4.07-4.37 (m, 4H); MS m/z (\%): $352\left(\mathrm{M}^{++}\right.$, 5), 264 (10), 224 (6), 176 (14), 136 (92), 104 (15), 71 (98), 43 (100).

Synthesis of 1,2,5-Dithiaselenepanes (5). General Procedure. A solution of thiirane $1(2 \mathrm{mmol})$ and HMDSS (1 mmol) in dry THF ( $3 \mathrm{~mL})$ was cooled under inert atmosphere at $0^{\circ} \mathrm{C}$ and treated with TBAF ( $0.2 \mathrm{~mL}$ of $1 \mathrm{M}$ THF solution, $0.2 \mathrm{mmol}$ ). After warming to room temperature and stirring for about $12 \mathrm{~h}$, the solution was diluted with diethyl ether, washed with water then with brine, and dried over $\mathrm{Na}_{2} \mathrm{SO}_{4}$. The solvent was evaporated under vacuum affording a crude product, which was purified on silica gel (petroleum ether/diethyl ether).

3,7-Di(but-3-en-1-yl)-1,2,5-dithiaselenepane (5a). IA mixture of two diastereoisomers; yellow oil (68\%). ${ }^{1} \mathrm{H}$ NMR (200 MHz, $\mathrm{CDCl}_{3}$ ) $\delta$ ppm: 1.48-1.73 (m, $4 \mathrm{H}), 1.98-2.35(\mathrm{~m}, 4 \mathrm{H}), 2.65-3.18(\mathrm{~m}, 6 \mathrm{H}), 4.96-5.11$ (m, 4H), 5.61-5.84 (m, 2H); MS $m / z(\%): 308\left(\mathrm{M}^{+}\right.$, 9), 226 (5), 194 (8), 145 (15), 113 (47), 81 (100), 41 (73).

3,7-Dimethyl-1,2,5-dithiaselenepane (5b). The product was purified by flash column chromatography (petroleum ether/diethyl ether 25:1) to give $\mathbf{5 b}$ as a mixture of two diastereoisomers. Yellow oil $(67 \%) .{ }^{1} \mathrm{H}$ NMR (200 MHz, $\left.\mathrm{CDCl}_{3}\right) \delta \mathrm{ppm}: 1.24-1.43$ (m, 6H), $2.93(\mathrm{dd}, J=13.8,6.4 \mathrm{~Hz}, 2 \mathrm{H}), 3.14(\mathrm{dd}$, $J=13.8,3.8 \mathrm{~Hz}, 2 \mathrm{H}), 3.18-3.42(\mathrm{~m}, 2 \mathrm{H}) ;{ }^{13} \mathrm{C} \mathrm{NMR}$ (50 MHz, $\mathrm{CDCl}_{3}$ ) $\delta$ ppm: 20.1, 20.8, 34.6, 38.3, 41.2 .

3,7-Dibutyl-1,2,5-dithiaselenepane (5c). A mixture of two diastereoisomers; yellow oil $(87 \%) .{ }^{1} \mathrm{H}$ NMR $\left(400 \mathrm{MHz}, \mathrm{CDCl}_{3}\right) \delta$ ppm: 0.86-0.93 (m, 6H), 1.23-1.75 (m, 12H), 2.58-3.23 (m, 6H); ${ }^{13} \mathrm{C} \mathrm{NMR}$ $\left(100 \mathrm{MHz}, \mathrm{CDCl}_{3}\right) \delta$ ppm: 13.7, 22.3, 24.7, 26.6, 28.9, 29.2, 32.3, 32.6, 34.1.

3,7-Bis(isopropoxymethyl)-1,2,5-dithiaselene-

pane (5d). A mixture of two diastereoisomers; yellow oil $(85 \%) .{ }^{1} \mathrm{H}$ NMR $\left(200 \mathrm{MHz}, \mathrm{CDCl}_{3}\right) \delta \mathrm{ppm}$ : 1.14 (ap.d, $J=6.4 \mathrm{~Hz}, 12 \mathrm{H}), 2.91-3.28(\mathrm{~m}, 6 \mathrm{H})$, 3.40-3.68 (m, 6H); ${ }^{13} \mathrm{C}$ NMR (50 MHz, $\left.\mathrm{CDCl}_{3}\right) \delta$ ppm: 22.1, 29.7, 49.5, 69.9, 70.1, 72.2; MS $\mathrm{m} / \mathrm{z}(\%)$ : $344\left(\mathrm{M}^{+}\right.$, 5), $244(6), 137$ (5), 121 (7), 99 (31), 73 (33), 59 (12), 57 (100), 43 (93).

3,7-Bis((benzyloxy)methyl)-1,2,5-dithiaselene-

pane (5e). A mixture of two diastereoisomers; yellow oil $(73 \%) .{ }^{1} \mathrm{H}$ NMR $\left(200 \mathrm{MHz}, \mathrm{CDCl}_{3}\right) \delta$ ppm: 2.89-3.31 (m, 6H), 3.47-3.91 (m, 4H), 4.53-4.55 (m, 4H), 7.28-7.35 (m, 10H); MS m/z (\%): $440\left(\mathrm{M}^{+}, 2\right)$, 292 (2), 147 (4), 107 (7), 91 (100), 73 (7), 65 (9). 
(3S, 7S)-3, 7-Bis((benzyloxy)methyl)-1,2,5dithiaselenepane (5f). Yellow oil $(71 \%) .{ }^{1} \mathrm{H}$ NMR $\left(200 \mathrm{MHz}, \mathrm{CDCl}_{3}\right) \delta \mathrm{ppm}: 2.91-3.32(\mathrm{~m}, 6 \mathrm{H}), 3.61-$ $3.78(\mathrm{~m}, 4 \mathrm{H}), 4.54$ (ap.s, 4H), 7.31-7.36 (m, 10H); ${ }^{13} \mathrm{C}$ NMR (50 MHz, $\left.\mathrm{CDCl}_{3}\right) \delta$ ppm: 29.6, 49.2, 72.1, 73.3, 127.6, 127.7, 128.4, 137.9; MS m/z (\%): 440 $\left(\mathrm{M}^{+} \cdot, 2\right), 292$ (2), 147 (4), 107 (7), 91 (100), 73 (7), 65 (9).

3,7-Bis((allyloxy)methyl)-1,2,5-dithiaselenepane

(5g). The product was purified by flash column chromatography (petroleum ether/diethyl ether 8:1) to give $\mathbf{5 g}$ as a mixture of two diastereoisomers. Yellow oil $(73 \%) .{ }^{1} \mathrm{H}$ NMR $\left(400 \mathrm{MHz}, \mathrm{CDCl}_{3}\right) \delta \mathrm{ppm}$ : 3.01-3.22 (m, 6H), 3.37-3.76 (m, 4H), 3.97-4.05 (m, $4 \mathrm{H}), 5.18-5.30(\mathrm{~m}, 4 \mathrm{H}), 5.81-5.98(\mathrm{~m}, 2 \mathrm{H}) ;{ }^{13} \mathrm{C} \mathrm{NMR}$ $\left(100 \mathrm{MHz}, \mathrm{CDCl}_{3}\right) \delta \mathrm{ppm}: 29.6,49.1,71.9,72.2,72.8$, $117.4,134.5 ;{ }^{77} \mathrm{Se}$ NMR $\left(38 \mathrm{MHz}, \mathrm{CDCl}_{3}\right) \delta \mathrm{ppm}$ : 133.8, 134.7; MS $m / z$ (\%): $340\left(\mathrm{M}^{+}, 6\right), 283(8), 242$ (9), 225 (5), 185 (7), 151 (6), 129 (15), 121 (21), 97 (60), 73 (100), 55 (58).

\section{REFERENCES}

[1] Block, E. Garlic and Other Alliums; Royal Society of Chemistry: Cambridge, UK, 2010.

[2] Inter alia: (a) Krafft, C.; Brennecke, S.; Ott, F.; Backes, M.; Salzer, R.; Grunenberg, J.; Ley, J. P.; Krammer, G. E.; Weber, B. Chem Biodiversity 2008, 5, 1204; (b) Alam, A.; Kon-no, M.; Ogawa, S.; Sato, R. Tetrahedron 2007, 63, 927; (c) Satoh, S.-I.; Sato, R. Tetrahedron Lett 1992, 33, 2517; (d) Harpp, D. M.; Smith, R. A. J Am Chem Soc 1982, 104, 6045; (e) Chenard, B. L.; Harlow, R. L.; Johnson, A. L.; Vladuchick, S. A. J Am Chem Soc 1985, 107, 3871.

[3] (a) Schulz, S.; Dickschat, J. S.; Kunze, B.; WagnerDobler, I.; Diestel, R.; Sasse, F. Mar Drugs 2010, 8, 2976; (b) Sobik, P.; Grunenberg, J.; Böröczky, K.; Laatsch, H.; Wagner-Dobler, I.; Schulz, S. J Org Chem 2007, 72, 3776; (c) Wratten, S. J.; Faulkner, D. J. J Org Chem 1976, 41, 2465.
[4] (a) Musorin, G. K.; Amosova, S. V.; Shcherbakov, V. V. Bull Acad Sci USSR, Div Chem Sci 1990, 39, 2423; (b) Musorin, G. K.; Amosova, S. V.; Kalabin, G. A. Chem Heterocycl Compd 1989, 25, 401; (c) Musorin, G. K.; Amosova, S. V. J Org Chem USSR 1987, 23, 1993; (d) Chernyshev, E. A.; Kuz'min, O. V.; Lebedev, A. V.; Gusev, A. I.; Los, M. G.; Alekseev, N. V.; Nametkin, N. S.; Tyurin, V. D.; Krapivin, A. M.; Kubasova, N. A.; Zaikin, V. G. J Organomet Chem 1983, 252, 143.

[5] (a) Wirth, T. (Ed.); Organoselenium Chemistry; WileyVCH: Weinheim, Germany, 2012; (b) Nogueira, C. W.; Zeni, G.; Rocha, J. B. T. Chem Rev 2004, 104, 6255; (c) Mugesh, G.; duMont, W.-W.; Sies, H. Chem Rev 2001, 101, 2125; (d) Nicolaou, K. C.; Petasis, N. A. Selenium in Natural Products Synthesis; CIS: Philadelphia, PA, 1984 and references cited therein; (e) Klayman, D. L.; Günter, W. H. H. In Organoselenium Compounds: Their Chemistry and Biology; WileyInterscience: New York, 1973.

[6] Inter alia: (a) Santi, C.; Santoro, S. In Organoselenium Chemistry; Wirth, T. (Ed.); Wiley-VCH: Weinheim, Germany, 2012; Ch. 1; (b) Singh, D.; Deobald, A. M.; Camargo, L. R. S.; Tabarelli, G.; Oscar, E. D.; Rodrigues, O. E. D.; Braga, A. L. Org Lett 2010, 12, 3288; (c) Młochowski, J.; Lisiak, R. Synth Commun 2009, 39, 3141; (d) Tiecco, M.; Testaferri, L.; Santi, C.; Tomasini, C.; Santoro, S.; Marini, F.; Bagnoli, L.; Temperini, A. Eur J Org Chem 2006, 21, 4867.

[7] Degl'Innocenti, A.; Capperucci, A.; Castagnoli, G.; Malesci, I. Synlett 2005, 1965.

[8] (a) Capperucci, A.; Tiberi, C.; Pollicino, S.; Degl'Innocenti, A. Tetrahedron Lett 2009, 50, 2808; (b) Capperucci, A.; Degl'Innocenti, A.; Pollicino, S.; Acciai, M.; Castagnoli, G.; Malesci, I. Heteroatom Chem 2007, 18, 516; (c) Degl'Innocenti, A.; Pollicino, S.; Capperucci, A. Chem Commun 2006, 4881; (d) Degl'Innocenti, A.; Capperucci, A.; Cerreti, A.; Pollicino, S.; Scapecchi, S.; Malesci, I.; Castagnoli, G. Synlett 2005, 3063.

[9] (a) Capperucci, A.; Tanini, D.; Degl'Innocenti A. Phosphorus Sulfur Silicon Relat Elem 2013, 188, 437; (b) Capperucci, A.; Degl'Innocenti, A.; Tiberi, C. Synlett 2011, 2248; (c) Degl'Innocenti, A.; Capperucci, A.; Castagnoli, G.; Malesci, I.; Tiberi, C.; Innocenti, B. Phosphorus Sulfur Silicon Relat Elem 2008, 183, 966. 